\title{
1 The formation of giant clastic extrusions at the end of the Messinian
}

\section{Salinity Crisis}

3 Christopher Kirkham ${ }^{a^{*},}$, Joe Cartwright ${ }^{a}$, Christian Hermanrud $^{b}$, Christopher Jebsen $^{c}$

${ }^{a}$ Department of Earth Sciences, University of Oxford, South Parks Road, Oxford, UK

${ }^{b}$ Statoil ASA, N-7005 Trondheim, Norway

' Statoil, N4032 Stavanger, Norway

$7 *$ Corresponding author

E-mail address: christopher.kirkham@earth.ox.ac.uk

This paper documents the discovery of five multi-km scale lensoid bodies that directly overlie the upper surface of the thick $(>1 \mathrm{~km})$ Messinian Evaporite sequence. They were identified through the analysis of 3D seismic data from the western Nile Cone. The convergence of the upper and lower bounding reflections of these lensoid bodies, their external and internal reflection configuration, the positive 'depositional' relief at their upper surface, and the stratal relationship with underlying and overlying deposits supports the interpretation that these are giant clastic extrusions. The interpretations combined with the stratal position of these clastic extrusions demonstrate a prior unsuspected link between periods of major environment change and basin hydrodynamics on a plate scale.

All five lensoid bodies were extruded onto a single, seismically resolvable marker horizon correlatable with the end of the Messinian Salinity Crisis (Horizon M). It is argued that the source of these clastic extrusions is pre-Messinian in origin, which implies massive 
sediment remobilisation at depth in the pre-evaporitic succession and intrusion through the thick evaporite layer. We propose that the scale and timing of this dramatic event was primed and triggered by near-lithostatic overpressure in the pre-evaporitic sediments generated through (1) their rapid burial and loading during the Messinian Salinity Crisis and (2) catastrophic re-flooding during its immediate aftermath. amongst the largest extruded sedimentary bodies described on Earth. The findings extend the understanding of the upper scale of other analogous clastic extrusions such as mud volcanoes and sediment-hosted hydrothermal systems. Following the 2006 eruption of the Lusi sediment-hosted hydrothermal system in Indonesia, an understanding of the upper scale limit of clastic extrusions has even greater societal relevance, in order to increase awareness of the risk posed by the potential size and longevity of future giant clastic extrusions.

The remobilisation and eruption of clastics at the seabed or surface during the formation of clastic extrusions including mud volcanoes and sediment-hosted hydrothermal systems is significant for several reasons: (1) they provide a route for methane flux to the atmosphere, (2) their flux can vary as a prior indication or response to earthquakes, (3) they are indicative of major basinal hydrodynamic perturbations, (4) they represent a geological 
hazard that can have a significant impact on human society if extruded in a populated area (Mazzini and Etiope, 2017; Milkov, 2000). This is demonstrated by the societal impact that the 2006 eruption of the Lusi sediment-hosting hydrothermal system had on the population of the Porong sub district, within the Sidoarjo district in east Java (Rudolph et al., 2011; Davies et al., 2008; Mazzini et al., 2007). Clastic extrusions are widely developed in highly mobile tectonic belts and in some intra-plate settings (see Kopf, 2002). They are particularly prevalent in settings that experience rapid sedimentation, thrust loading, active horizontal tectonic compression or in igneous and hydrothermal systems (Milkov, 2000; Mazzini and Etiope, 2017).

An interesting open question exists as to the upper scale limit of clastic extrusions.

Documented estimates for the largest mud volcanoes are variable and range from $12 \mathrm{~km}^{3}$ to $22.3 \mathrm{~km}^{3}$ to potentially $>100 \mathrm{~km}^{3}$ (Davies and Stewart, 2005; Kopf et al., 2001; Mazzini and Etiope, 2017). A better understanding of the upper scale limit of clastic extrusions is important to fully explain these natural phenomena.

Periods of major environmental or regional tectonic perturbations can have a significant impact on the hydrodynamic regime at depth within a basin. Focused fluid venting events associated with the Messinian Salinity Crisis (MSC) have been increasingly documented in recent years (see Bertoni and Cartwright (2015) for review), particularly linked to the early stages of the crisis. For example, in the Levant Basin (Eastern Mediterranean) pockmark craters at the base of the Messinian have been linked to methane venting as a response to the drawdown of the water column and unloading of pre-Messinian overpressured gas accumulations at the 
destabilisation of gas hydrates in the Western Mediterranean Basin (Lorca Basin, SE Spain).

The breakdown of gas hydrates resulted in the release of large amounts of methane and caused sedimentary instability of Tortonian marls (Pierre et al., 2002). Sedimentary instability within Tortonian sediments in the Western Mediterranean Basin (Lorca Basin, SE Spain) due to the release of large amounts of methane during the destabilisation and breakdown of gas hydrates within Tortonian marls has also been correlated with the Messinian drawdown (Pierre et al., 2002). In addition, late Messinian fluid expulsion (mainly methane) through mud volcano conduits that transect the Messinian succession have been correlated to the drawdown in sea level at 5.55 $\mathrm{Ma}$ in the Central Mediterranean, along the basin margin (ladanza et al., 2013).

There is, however, an absence of evidence for large-scale fluid venting events associated with the terminal stages of the MSC. This is surprising given that it has been postulated that rapid evaporite deposition and late MSC sea level fluctuations may have had a significant impact on basinal hydrodynamics (Bertoni and Cartwright, 2015).

In this paper we present evidence for a major, short-lived, volumetrically dramatic phase of sediment remobilisation and extrusion that occurred at the termination of the MSC. The evidence is based on 3D seismic interpretation of a group of large lensoid sedimentary bodies, the upper surfaces of which downlap onto Horizon $M$ (regionally defined as the marker for the end of the MSC). The seismic survey is located in the western portion of the Nile Cone where earlier studies have identified significant Pliocene and younger mud 87 volcanism (Loncke et al., 2004; Mascle et al., 2014; Kirkham et al., 2017b; Dupré et al., 2010; Giresse et al., 2010; Prinzhofer and Deville, 2013) (Fig. 1). The main aims of this paper are to describe and account for the origin of these unusual lensoid bodies and place them in a wider 
genetic context with reference to well constrained events occurring in the Mediterranean Basin at this time of extreme environmental change at the end of the MSC.

We propose that the most likely explanation for the lensoid bodies is that they are giant clastic extrusions. The findings presented within this paper further develop the understanding of the upper scale of clastic extrusions. This has significant implications for our understanding of: (1) the potential risk and societal impact that future large scale clastic extrusions could pose to populated regions; (2) predicting the potential longevity of modern clastic extrusions such as the Lusi sediment-hosted hydrothermal system; (3) a previously undocumented major basinal hydrodynamic event that is correlatable within the terminal stages of the MSC; (4) prior unsuspected links between periods of major environment change and basin hydrodynamics on a plate scale.

\section{Geological context}

The study area is located at the south-western distal limit of the Nile Cone, which is the deepwater continuation of the Nile Delta (Fig. 1). This major progradational depositional system built out over the passive continental margin of north-eastern Africa in the Mid-Late Cenozoic, following the capture of the River Nile in the Oligocene (Macgregor, 2012). The Cenozoic development of this passive margin followed prolonged rifting in the Tethyan realm from the Triassic to the Early Cretaceous (Loncke et al., 2004; Dolson et al., 2005). The major extensional faults that comprise the main structural elements of this margin formed initially during Triassic rifting, but were later partially reactivated during the Miocene rifting of the Suez-Red Sea Rift System (Aal et al., 2000; Loncke et al., 2004). 
113 Salinity Crisis (MSC). The onset of the MSC, recently dated at 5.97 Ma, commenced due to 114 progressive disconnection of the Mediterranean from the Atlantic, coupled by a drawdown 115 in sea level currently estimated in the range of a few hundred meters to over $1000 \mathrm{~m}$ (e.g. 116 Rouchy and Caruso (2006) and Roveri et al. (2016)). A subsequent restriction in water 117 circulation and isolation of the Mediterranean Basin led to the temporary abandonment of 118 progradation of marginal depositional systems (Roveri et al., 2016). The widespread arrest of clastic input into the basin was followed by deposition of a thick unit (up to $3 \mathrm{~km}$ within some 120 deeper basins) of evaporites, the majority of which (mainly halite) were deposited over a geologically short period of time, with estimates ranging from as little as 60 kyrs to over 600 kyrs (e.g. Roveri et al. (2016) and Meilijson et al. (2017)). the global datum occurred at $5.33 \mathrm{Ma}$ in a dramatic event known as the Zanclean Flood (Garcia-Castellanos et al., 2009). Recent modelling of this re-flooding event shows that $90 \%$ of the refill could have occurred in a sudden flood spanning a few months to two years, with peak sea level rise rates of $>10 \mathrm{~m}$ a day (Garcia-Castellanos et al., 2009). a large post-evaporitic slope apron throughout the Pliocene to Recent, forming an extensive sedimentary wedge that covers c. $100,000 \mathrm{~km}^{2}$ and extends northwards towards the

131 Mediterranean ridge and Eratosthenes Seamount (Macgregor, 2012). Salt tectonics associated with tilting and differential loading of the Messinian Evaporites by the Nile Cone

133 has strongly influenced the structure of the post-Messinian succession (Loncke et al., 2004;

134 Cartwright and Jackson, 2008). 


\section{Data and methodology}

This study is based on the analysis of high resolution 3D pre-stack time (PSTM) and depth (PSDM) migrated seismic data extending over a survey area of $\sim 4300 \mathrm{~km}^{2}$ located at water depths ranging from c. $2500-3000 \mathrm{~m}$. The binset dimensions of $12.5 \times 6.25 \mathrm{~m}$ yield a lateral resolution of c. $25 \mathrm{~m}$ throughout the post-evaporitic overburden. The data is zero

141 phased with SEG normal polarity, i.e. an increase in acoustic impedance is represented by a

142 positive amplitude response. Vertical seismic resolution is $\sim 3 \mathrm{~m}$ (Frequency $-125 \mathrm{~Hz}$; Velocity

$143-1520 \mathrm{~m} / \mathrm{s}$ ) at the seabed, $8 \mathrm{~m}$ (Frequency $-60 \mathrm{~Hz}$; Velocity - $1800 \mathrm{~m} / \mathrm{s}$ ) within the postevaporitic overburden and $\sim 30 \mathrm{~m}$ (Frequency $-35 \mathrm{~Hz}$; Velocity - $4400 \mathrm{~m} / \mathrm{s}$ ) at the Top evaporite (Fig. 2).

The seismic data was interpreted using standard seismic-stratigraphic techniques adapted for modern 3D seismic volumes (Brown, 2005). All stratigraphically significant marker horizons were correlated throughout the survey area. Mapping was an iterative process using pre-stack time migrated (PSTM) seismic and pre-stack depth migrated (PSDM) seismic. Volumetric computations based on the mapped horizons were made using the PSDM volume.

Depth conversion was based on interval velocities obtained from the PSDM processing, which are subject to errors of about $10 \%$ typically due to iterative picking of migration velocities that

153 give the best geological fit (Bacon et al., 2007; Brown et al., 2004).

The main intervals of interest for this study were the stratigraphic units developed immediately preceding, during and after the MSC. The base and top of the main evaporitic interval is defined by the reflections of Horizons $N$ and $M$ (Fig. 2), in accordance with 
stratigraphic definitions from neighbouring areas in the SE Mediterranean (e.g. Bertoni and

Cartwright (2005)). One other important horizon interpreted from this seismic survey, termed

159 here as Horizon L, is developed only locally in the study area, and exhibits an unusual relationship with Horizon $\mathrm{M}$, locally converging to a single common reflection (Fig. 2). This key marker horizon is described in detail below.

\section{Observations from 3D seismic data}

\section{$164 \quad 4.1 \quad$ Seismic stratigraphy}

The seismic stratigraphy of the study area is divided into three seismic units, following

Kirkham et al. (2017b), and based on the contrasting seismic expression of the units and long range correlation to wells in neighbouring regions (Bertoni and Cartwright, 2005). These seismic units are termed here the Pre-Evaporitic Unit, the Messinian Evaporites and the PostEvaporitic Unit (Fig. 2). and velocity anomalies relating to the overlying high velocity evaporites. It consists of weak

172 to high amplitude reflections with variable continuity. It is deformed by a number of basement faults that in part control the thickness distribution. The upper section of this unit

174 is characterised by an onlapping wedge that thins towards the southwest (Fig. 2). The unit is bound at its top by the 'soft' reflection of Horizon N (Fig. 2 and Fig. 3A).

177 chaotic seismic facies (Fig. 2), typical of the halite-rich Messinian succession documented 
further to the east (c.f. Bertoni and Cartwright (2007)). This wedge-shaped unit exhibits an

179 increase of thickness to $>1 \mathrm{~km}$ towards the northeast of the study area. The top of the 180 Messinian Evaporites (Horizon M) is characterised by a high amplitude and 'hard' reflection

181 that is regionally correlatable and demarcates the end of evaporite deposition (Loncke et al.,

182 2004; Bertoni and Cartwright, 2007) (Fig. 2). Horizons M and Horizon N exhibit irregular 183 geometry of hundreds of metres of relief (Fig. 2 and Fig. 3). Numerous large, circular to 184 irregular depressions greater than $1000 \mathrm{~m}$ deep are evident on the structure map of Horizon $185 \mathrm{M}$, while Horizon $\mathrm{N}$ similarly shows large depressions up to $800 \mathrm{~m}$ depth and localised and 186 often linear areas of positive structural relief of up to $700 \mathrm{~m}$ (Fig. 2 and Fig. 3). The Post-Evaporitic Unit is Pliocene to Recent in age and predominantly comprises a highly coherent reflective depositional unit, with variable amplitude, and high lateral continuity and frequency (Fig. 2). These seismic facies are considered typical of hemipelagic deposits similar to those documented within other regions of the Eastern Mediterranean (Bertoni and Cartwright, 2005; Dupré et al., 2010). The unit is deformed by a series of E-W striking growth faults that detach within the underlying evaporites (Fig. 1). A large number (> 350) small mud volcanoes are embedded within this Post-Evaporitic Unit. These range in age from Early Pliocene to Recent (Kirkham et al., 2017b). 110 mud volcanoes have been mapped at the modern seafloor, and are either still active or have become recently inactive (Fig. 1).

\subsection{Lensoid bodies above Horizon $M$}


evaporite (Horizon M) depressions (Fig. 3B and Fig. 4). The size and relief of these depressions

201 is related to the size of the lensoid bodies: the largest of these depressions (up to $800 \mathrm{~m}$ deep and $20 \mathrm{~km}$ long) occur beneath large lensoid bodies. Numerous other small depressions occur beneath small lensoid bodies, recently shown by Kirkham et al. (2017b) to have formed via localised subsidence associated with the genesis of depletion zones within the Pre-Evaporitic Unit during mud volcanism. These five bodies exhibit irregular planforms (Fig. 3). Seismic profiles through their centres reveal their internal geometry to be consistently lensoid, with convex upward geometry (Fig. 4). Their maximum vertical thickness ranges from $660 \mathrm{~m}$ to $1190 \mathrm{~m}$, their widths range from $3.27 \mathrm{~km}$ to $28.60 \mathrm{~km}$ and their volumes range from $1.25 \mathrm{~km}^{3}$ to $116 \mathrm{~km}^{3}$ (Table 1). They are all thickest close to the centre of the body, becoming progressively thinner towards the marginal convergence of their upper and lower bounding surfaces (e.g. Fig. 4).

The lensoid bodies are represented as a chaotic to discontinuous, low frequency, and generally low amplitude seismic facies with some localised high amplitude anomalies 214 developed internally (Fig. 4A and Fig. 4B). They are distinctive from the clastic units in the Post-Evaporitic Unit and Pre-Evaporitic Unit in that there is no internal stratification observable developed within them (Fig. 2, Fig. 4A and Fig. 4B). The seismic facies of the

217 lensoid bodies and the immediately underlying Messinian Evaporites are similar, but the 218 continuity of the hard reflection of Horizon $\mathrm{M}$ allows them to be distinguished and mapped separately. The seismic velocities derived from the PSDM also show a marked difference, with

220 the lensoid bodies being consistently in the $2000-2500 \mathrm{~m} / \mathrm{s}$ range, whereas the Messinian 

margins of the lensoid bodies are delineated by the convergence of Horizons L and M (Fig. 4C and Fig. 4D). The convergence of these two marker reflections provides a stratigraphic definition for the base of the lensoid bodies, and further confirms their differentiation from the underlying Messinian Evaporites. A sharp parallel onlap of the overlying hemipelagites of the Post-Evaporitic Unit onto Horizon L is observable, in places, around the lateral margins of these bodies (Fig. 4C). The onlap geometry is characterised by a single seismically resolvable onlap surface, which implies that there was no interdigitation of the overlying hemipelagites with the filling material of the lensoid body (c.f. Cartwright et al. (1993) E-W trending syn-sedimentary faults that detach within the Messinian Evaporites. This faulting forms part of a regional gravity-driven deformation that exploited the weakness of the Messinian Evaporites during Late Pliocene to Recent tilting and differential loading of this part of the continental margin (Loncke et al., 2004; Cartwright and Jackson, 2008). The faulting thus post-dates the emplacement of the lensoid bodies, and accounts for their complex present day geometry, with often substantial offsets and rotation of their original geometry (Supplementary Fig. 1).

\subsection{Detailed description of the lensoid bodies}

The five lensoid bodies exhibit considerable variation in geometry and seismic expression. This variation is described below with reference to a selection of three of these 
lensoid bodies that best illustrate the full range of detailed features observed on the seismic 244 data.

\subsubsection{Lensoid Body 1}

LB1 is located in the south central part of the study area and is the largest of the lensoid bodies in the study area with a volume of $116 \mathrm{~km}^{3}$ (Table 1 and Fig. 3). It is asymmetrical in cross-section, has an irregular planform (Fig. 5). The geometry of Horizon L is dominated by a prominent central ridge that coincides with the thickest development of the body (Fig. 5B and Fig. 5C). The geometry of the onlap onto Horizon L implies that this upper bounding surface of LB1 was expressed as a paleo-topographic relief of c. $300 \mathrm{~m}$ (not corrected for compaction) (Fig. 5D).

In the region directly below LB1, Horizon $\mathrm{N}$ consists of several depressions and a complex ridge structure (visible in time and depth migrated data) which is spatially aligned with the thickest part of the lensoid body and region of greatest relief at Horizon M (Fig. 3A, Fig. 5A and Fig. 5B). This results in a localised thinning of the Messinian Evaporites and convergence, or welding, of the Pre-Evaporitic Unit and lensoid body (Fig. 5A and Fig. 5B). Seismic imaging beneath Horizon $\mathrm{N}$ is poor, particularly beneath the region of welding. However, pre-evaporite reflections are offset and exhibit an abrupt change of gross dip across this zone of disruption, consistent with deformation of this interval by a major fault (Fig. 5A and Fig. 5B). The spatial correlation between this major structure in the Pre-Evaporitic Unit and the ridge-like zone of welding strongly suggests a genetic link between the faulting and the emplacement of the lensoid body, but the imaging quality of the seismic data on both 
PSTM and PSDM volumes is too poor to be more explicit as to the nature of this relationship i.e. whether this was passive and exploitative, or active and causative.

\subsubsection{Lensoid Body 2}

LB2 is located within the north westerly region of the study area (Fig. 3), is the thickest of the five lensoid bodies and the second largest with a volume of $52 \mathrm{~km}^{3}$ (Table 1 and Fig. 6).

271 It is elongated in an E-W orientation and is c. $20 \mathrm{~km}$ in length (Fig. 6C). As with LB1, its geometry is dominated by a prominent central ridge coinciding with the thickest part of the body. It is more symmetrical at Horizon L, with northern and southern flanks whose original dip at the time of deposition of the lensoid body are estimated to be c. 6-7 $7^{\circ}$ (Fig. 6A and Fig. 6B). These flank dips are based on present day geometry of the parallel onlap fill onto Horizon L, with an assumption that the onlapping units were deposited horizontally (c.f. Brown Jr and Fisher (1977)) (Fig. 6D). This estimate is conservative because in the absence of direct well calibration of lithology, the angular relationships have not been corrected for later compaction. The magnitude of the paleo-topographic relief is estimated to be a minimum of $350 \mathrm{~m}$, from the undecompacted thickness of the parallel onlap fill reflections (Fig. 6D).

Similarly to LB1, a prominent ridge is visible at Horizon N, directly underlying an up to 800 m deep depression at Horizon M (Fig. 3A, Fig. 6A and Fig. 6B). Localised thinning of the Messinian Evaporites is pronounced beneath LB2, such that a direct juxtaposition of the PreEvaporitic Unit and LB2 occurs directly beneath the thickest part of LB2 (Fig. 6A and Fig. 6B). Horizons $\mathrm{M}$ and $\mathrm{N}$ are welded at this position (Fig. $6 \mathrm{~A}$ and Fig. 6B). A large offset of Horizon $\mathrm{N}$ across this central zone (Fig. 6B), is consistent with a partly concealed, deeper structure within 
the Pre-Evaporitic Unit underlying the lensoid body but imaging artefacts render the deeper structural interpretation uncertain (c.f. Fig 6A and Fig 6B).

\subsubsection{Lensoid Body 3}

LB3 is the smallest of the lensoid bodies (Table 1), located within the north to central region of the study area (Fig. 3). Despite its total volume of only $1.25 \mathrm{~km}^{3}$ it nonetheless exhibits an undecompacted paleo-topographic relief of up to $250 \mathrm{~m}$ (Fig. 7A and Fig. 7B). LB3 contrasts with the other lensoid bodies in that its planform is elliptical rather than irregular (Fig. 3 and Fig. 7C) and in cross sectional it is more symmetric (Fig. 7A and Fig. 7B) resulting in a grossly conical 3D geometry. LB3 has markedly steeper flanks $\left(14^{\circ}\right.$, uncorrected, estimated from parallel onlap configuration) than LB1 and LB2. (Fig. 7D). In contrast to LB1 and LB2, the Messinian Evaporites do not thin significantly beneath the lensoid body, nor do Horizon M and Horizon $\mathrm{N}$ converge (Fig. 7A and Fig. 7B).

300

\section{DISCUSSION}

\section{$302 \quad 5.1 \quad$ Interpretation of the lensoid bodies}

The preceding descriptive sections can be summarised with the following key observations regarding the context and detailed geometry of the five lensoid bodies: 
1. Convergence of Horizon L exclusively onto Horizon $M$ occurs at the lateral margins of the lensoid bodies and this defines a closed perimeter for each of the five bodies, with no seismically resolvable connection between them.

2. Horizon $L$ is defined partly by a single discrete onlap surface with no evidence of interdigitation between the onlapping reflections and the internal fill of the lensoid

3. The lensoid bodies are convex upwards with maximum thickness of 100 s of metres distributed in the central region, and original flank angles in the range 1 to $14^{\circ}$.

4. The lensoid bodies were expressed with a paleo-topographic relief at the depositional surface of several hundreds of metres.

5. The lensoid bodies lack any internally coherent reflectivity.

6. The lensoid bodies were all emplaced directly onto Horizon M, i.e. at the end of the

319 of the five lensoid bodies implies that these bodies were depositional, and exhibited 320 significant seafloor relief extant at Horizon L. The conservative estimates of the original flank 321 dips of this seafloor relief that commonly exceed $5^{\circ}$ argues that these lensoid bodies are 322 unlikely to be clastic sedimentary fans or sediment drifts. Submarine fans, alluvial fans and 323 contourite drifts typically exhibit upper surface dips of less than a few degrees and are 324 universally found to be internally stratified (Mitchum Jr, 1985; Blair and McPherson, 1994; 325 Faugères et al., 1999). Furthermore, both types of fan and drift bodies tend to be part of a connected depositional system, with feeder systems from updip in the basin (fans), or up- 
current in the flow regime (drifts), and there is no evidence for either types of feeder system here.

Two other types of more fully isolated depositional build-up could be considered, namely carbonate constructional mounds (Burgess et al., 2013), and hydrothermal mounds with associated hyaloclastites (Zhao et al., 2014). Both types of mound could exhibit the observed ranges of flank dips, relief, thickness and the areal dimensions, and commonly exhibit closed perimeters with similarly irregular planforms. However, carbonate mounds

334 tend to have high velocities at the observed depth range, often exceeding $3500 \mathrm{~m} / \mathrm{s}$ 335 (Vahrenkamp et al., 2004). This means that their upper bounding surfaces should be a high 336 amplitude, 'hard' reflection when overlain by acoustically 'soft' hemipelagites, as opposed to the moderate amplitude, 'soft' reflection consistently observed at Horizon L. Furthermore, carbonate mounds commonly exhibit internal stratification with a much higher amplitude seismic facies (Burgess et al., 2013). Igneous mounds or edifices also commonly exhibit internal stratification, a generally much higher interval velocity $(4000 \mathrm{~m} / \mathrm{s})$ and a more

341 irregular upper surface than that observed here (Davies et al., 2002; Magee et al., 2013).

342 Furthermore, we note that no volcanic rocks or carbonate mounds have been reported at this

343 stratigraphic position anywhere in the equivalent deeper basinal parts of the Mediterranean

344 Basin. These arguments make it unlikely that the lensoid bodies are constructional carbonate 345 or volcanic mounds.

An alternative interpretation that would fully explain the seismic stratigraphic observations presented earlier is that the lensoid bodies are related to mud volcanism, and represent large extrusive edifices. Kirkham et al. (2017b) recently reported evidence of extensive mud volcanism in the study area, albeit post-dating the lensoid bodies, and with 
much smaller dimensions. They mapped 386 individual mud cones from the early Pliocene to

351 the present day, with a mean volume per cone of c. $1 \mathrm{~km}^{3}$. This is a typical volume for mud 352 volcanoes on a global scale (Mazzini and Etiope, 2017; Graue, 2000; Calves et al., 2010). These are one to two magnitudes smaller in volume than LB1, 2, 4 and 5, but quite similar in size, geometry, seismic expression and planform to LB3 (Kirkham et al., 2017b) (Table 1 and Fig. 7; Supplementary Fig. 2). Mediterranean lends further support for this interpretation and provides possible analogues for the geometry and scale of these lensoid bodies as mud extrusions (Mascle et al., 2014). Large and irregular mud extrusions have been reported with similar dimensions to the lensoid bodies described here by Kopf et al. (2001) from the Mediterranean Ridge accretionary complex. These large 'mud pies' as termed by Kopf et al. (2001) share the convex upwards geometry and lack of internal stratification with the lensoid bodies described here. This analogy is further supported by the many studies that demonstrate widespread mud remobilisation from the Early Pliocene to Recent within this region (Loncke et al., 2004; Huguen et al., 2009; Dupré et al., 2010; Giresse et al., 2010; Dupré et al., 2014; Mascle et al., 2014; Pierre et al., 2014). geometrically more conical mud volcanoes mapped in the Pliocene and younger succession in the study area, both in geometry and in volume. Their irregular geometry is however more akin to that of the mud pies described by Kopf et al. (2001), which they attributed to the

371 influences of underlying structure and feeder systems. A similar explanation could apply here, accentuated by the significant deformation and faulting of the Post-Evaporitic Unit (including 
373 the lensoid bodies) associated with thin skinned gravity tectonics within the region

374 (Supplementary Fig. 1). Although the geometry of the lensoid bodies is irregular, as mud

375 volcanoes have become more widely studied awareness has grown as to the wide variety of 376 extrusional morphologies they can adopt (Mazzini and Etiope, 2017). In summary, we propose

377 that the most plausible interpretation of the lensoid bodies is that they are large extrusive 378 edifices. However, in the absence of direct calibration of these enigmatic bodies much 379 uncertainty remains as to the composition of the extruded clastics and as to the exact type of 380 geological phenomena they represent. Until the lensoid can be better calibrated we suggest 381 referring to them as giant clastic extrusions.

\subsection{Genesis of the giant clastic extrusions}

The interpretation of the lensoid bodies as clastic extrusions raises important questions regarding the hydrodynamic regime in the basin at the time of their extrusion at the termination of the MSC. Collectively and individually, these clastic extrusions represent a major flux of remobilised sediment from depth in this part of the basin, which implies the presence of a volumetrically extensive underlying source region (Kopf, 2002). The combined volume of all five lensoid bodies is greater than the total extruded volume recorded in 386 mud volcanoes mapped at a shallower level (Pliocene to Recent) in the same study area

391 (Kirkham et al., 2017b). 
395

396

397

398

399

400

401

402

403

404

405

406

407

408

409

410

411

412

413

414

415

This is considerably smaller than the volume of the largest three lensoid bodies as described here.

\subsubsection{Source}

The fact that the giant clastic extrusions were emplaced directly onto Horizon M (Fig.

4, Fig. 5, Fig. 6 and Fig. 7) implies that the source of the remobilised mud must have come from beneath the evaporitic unit. A pre-Messinian Evaporite source was also invoked by Kirkham et al. (2017b) to explain the source for the large number of smaller mud volcanoes in the Post-Evaporitic Unit of this area. Evidence cited includes piston cores taken from recent mud volcanism that contain pre-Messinian clasts, gas seepage samples in part comprised of very mature thermogenic gas and hot saline pools associated with evaporite dissolution as documented evidence (Huguen et al., 2009; Giresse et al., 2010; Prinzhofer and Deville, 2013; Dupré et al., 2014; Mascle et al., 2014; Pierre et al., 2014). The remobilisation and withdrawal of large volumes of sediment from this interval and the subsequent formation of pronounced pre-Messinian depletion zones would also account for much of the irregular geometry seen at Horizon N (Fig. 3A) (c.f. Stewart and Davies (2006); Kirkham et al, (2017)).

\subsubsection{Overpressure and remobilisation mechanisms}

Remobilisation and extrusion of such huge volumes of clastic sediments implies that the source region was highly overpressured at the time of the extrusion event (Mazzini and Etiope, 2017), or was susceptible to remobilisation through some other process leading to 
416 liquefaction (Rudolph et al., 2011). We propose a model for the formation of the giant clastic

417 extrusions described here, that attributes the extraordinary flux of extruded sediment at the

418 end of the MSC to the hydrodynamic impact of the rapid periods of environmental change associated with the MSC (Fig. 8).

By the end of the MSC at $5.33 \mathrm{Ma}$, large thicknesses (up to $2 \mathrm{~km}$ ) of evaporites had

421 accumulated over large regions of thick underlying clastic, dominantly fine-grained

422 sediments, including those in the study area. The evaporite deposition involved exceptional

423 sedimentation rates potentially up to c. 4 cm/yr (Roveri et al., 2016; Rouchy and Caruso, 2006)

424 (Fig. 8A). Such rapid deposition of a laterally extensive and extremely low permeability evaporite layer would have prevented or retarded compactional dewatering of the underlying sediments (Osborne and Swarbrick, 1997) and led to the build-up of significant overpressure beneath the evaporites in the putative source interval at depth beneath the Messinian Evaporites in the study area (Fig. 8A). pressure for hydraulic fracturing of the overlying evaporite seal was achieved. The stratigraphic position of all the mud volcanoes described here (LBs 1-5) directly on top of Horizon $M$, with no evidence of interdigitation with the evaporites, implies that this was achieved at the very final stages of the MSC. It is at this time (5.33 Ma) that Atlantic waters catastrophically and almost instantaneously (in terms of geological time) flooded through the

435 Gibraltar Strait refilling the Mediterranean during the Zanclean flood (Garcia-Castellanos et al., 2009) (Fig. 8B). The almost instantaneous loading of an estimated 1-2 km water column (Garcia438 Castellanos et al., 2009; Meijer and Krijgsman, 2005) would have resulted in a substantial 
increase in total vertical stress within and below the Messinian Evaporites the basin. It is not clear at present precisely how this rapid loading by the reflooding of the Mediterranean would have promoted remobilisation on such a scale, although at least locally effective stress must have reduced to zero for remobilisation to have occurred at all (Kopf et al., 2001; Rudolph et al., 2011). What is clear, is that the timing of the first major phase of clastic extrusion in this region coincides with the reflooding event, and it is hard to see this timing as a simple coincidence. exploitation of deformed zones in the source region might have led to specific feeders being located above underlying structures (Fig. 8B). Propagation of the feeder zones through the Messinian Evaporites would have promoted the depletion of clastic sediments and overpressured fluids from the source layer, and led to extrusion at the depositional surface (Horizon M), with large bodies built at the seabed, with relief of hundreds of metres (Fig. 8B). The steep flank angles probably indicate that the extruded sediment was relatively viscous, and low in water and gas content (c.f. Kopf, 2002) (Fig. 8B). seismic imaging on either the time or depth migrated volumes. Feeders for the Pliocene to Recent mud volcanoes in the study area have recently been shown to consist of cylindrical 457 pipe-like conduits (Kirkham et al., 2017a). However, it would be premature to invoke a similar 458 conduit geometry for the much larger and more irregular clastic extrusions. The planform of 459 the clastic extrusions and the geometry of the salt welds beneath them, together with the 460 presence of possible major faults directly beneath them instead hints at a different mode of conduit genesis. 

region $\left(<1000 \mathrm{~km}^{2}\right)$ would have resulted in a major pressure drop and re-equilibration of pressure in the source region and cessation of all extrusive activity. The remnant edifices would then have been passively onlapped by deep water hemipelagites after the reflooding event at $5.33 \mathrm{Ma}$ (Fig. 8C). Later burial and deformation during Late Pliocene to Recent gravity-driven salt tectonics modified the original geometry of the edifices and contributed to their final complex geometry (Fig. 8D).

\subsubsection{Implications}

The observations presented above strongly suggest that these clastic extrusions were formed in a single episode, so from this, is it possible to place any constraints on the likely duration of this extrusive period. interdigitation (e.g. Figs. 4C) implies that these bodies were extruded in a time period of no longer than that represented by the thin package of sediment embodied by this reflection.

477 Using the vertical seismic resolution of $10 \mathrm{~m}$, it is possible to estimate that the maximum 478 thickness of background sedimentation that could have been deposited coevally with the 479 extrusion amounts to no more than $40 \mathrm{~m}$, and is probably considerably less. This yields an 480 upper threshold for the eruptive duration of these clastic extrusions as 200 kyrs based on the local average sedimentation rates for the Pliocene to Recent interval of c. 200 m/Ma. 
extrusive analogue, we tentatively draw an analogy with the sediment-hosted hydrothermal system of Lusi, in east Java, Indonesia. Lusi has been erupting since 2006 with an average flux of $10^{4} \mathrm{~m}^{3} /$ day (3652420 $\mathrm{m}^{3} /$ year) (Mazzini et al., 2012). Applying this flux to the $116 \times 10^{9} \mathrm{~m}^{3}$ volume of LB1, yields an eruptive period of approximately 30 kyrs. In this context, even with the uncertainties in dating, the scale of these end Messinian extrusions is clearly orders of magnitude greater than many other documented clastic extrusions, and demonstrates the potential for long-lived clastic remobilisation and extrusion in single eruptive episodes. extreme clastic extrusion related disaster of modern times. Its eruption led to the submersion of several villages by fluidised sediment and displaced > 60,000 people (Mazzini et al., 2012; Rudolph et al., 2013). Based on the average flux recorded from Lusi $\left(10^{4} \mathrm{~m}^{3} / \mathrm{day}\right)$ the volume of sediment extruded since its eruption in 2006 can be estimated to be $<0.1 \mathrm{~km}^{3}$. The extruded volume of Lusi is hence 3 orders of magnitude smaller than the largest of the giant clastic extrusions (LB1) described here. Given the potential for disruption to life as seen in the Lusi example, it is important to acknowledge that if a clastic extrusion of the scale of LB1 were to form today in a populated region, it could pose a potentially significant threat to society. small area of the Eastern Mediterranean can be seen in the wider context of the basinal hydrodynamic impact of the MSC and the Zanclean flood. The identification of these giant clastic extrusions fills a gap in the record of the MSC, demonstrating for the first time evidence of a major basinal hydrodynamic event at its terminal stages. 
examples of focused fluid flow associated with this terminal stage of the MSC may also exist.

More widely, given the major causative influence of rapid loading during salt deposition, and

509 the widely documented role of thick salt sheets in developing overpressure in sedimentary basins, clastic extrusions of a similar or even larger scale may also potentially be present in

511 other salt basins around the world.

\section{Conclusion}

Five multi-km scale anomalous lensoid bodies have been identified within the western slope of the Nile Cone through the interpretation of 3D seismic reflection data. It is argued that the lensoid bodies were formed via a process of clastic remobilisation and extrusion of pre-salt sediments. The remobilised sediment therefore bypassed the thick evaporite sequence. We argue that the scale and timing of these extrusions was a response to the extreme priming and triggering mechanism of rapid burial and loading by evaporites during the MSC followed by catastrophic re-flooding during its terminal stages. event at the terminal stages of the MSC in the Mediterranean, which until now was merely postulated. We expect that other examples of focused fluid flow features that formed at this

524 time are likely to exist in other parts of the Mediterranean and indeed other salt basins worldwide. Acknowledging the existence and potential scale of clastic extrusions such as

526 these is important when considering the potential threat that future clastic extrusions could pose to society. 
530 We would like to thank Statoil for provision of the data used in this study and NERC for award

531 number BW22003102 that supported this research. We are also grateful to Schlumberger for

532 provision of the IESX and Petrel software suites for the seismic interpretation. We would like

533 to thank the Editor Professor An Yin and the reviewer Dr Adriano Mazzini for their

constructive feedback that truly helped to further develop the manuscript.

References

537

538

539

540

541

542

543

544

545

546

547

548

549

550

551

552

553

554

555

556

557

558

559

560

561

562

563

564

565

566

567

568

569

AAL, A. A., EL BARKOOKY, A., GERRITS, M., MEYER, H., SCHWANDER, M. \& ZAKI, H. 2000. Tectonic evolution of the Eastern Mediterranean Basin and its significance for hydrocarbon prospectivity in the ultradeepwater of the Nile Delta. The Leading Edge, 19, 1086-1102.

BACON, M., SIMM, R. \& REDSHAW, T. 2007. 3-D seismic interpretation, Cambridge University Press.

BERTONI, C. \& CARTWRIGHT, J. 2005. 3D seismic analysis of circular evaporite dissolution structures, Eastern Mediterranean. Journal of the Geological Society, 162, 909-926.

BERTONI, C. \& CARTWRIGHT, J. 2015. Messinian evaporites and fluid flow. Marine and Petroleum Geology, 66, 165-176.

BERTONI, C., CARTWRIGHT, J. \& HERMANRUD, C. 2013. Evidence for large-scale methane venting due to rapid drawdown of sea level during the Messinian Salinity Crisis. Geology, 41, 371-374.

BERTONI, C. \& CARTWRIGHT, J. A. 2007. Major erosion at the end of the Messinian Salinity Crisis: evidence from the Levant Basin, Eastern Mediterranean. Basin Research, 19, 1-18.

BLAIR, T. C. \& MCPHERSON, J. G. 1994. Alluvial fans and their natural distinction from rivers based on morphology, hydraulic processes, sedimentary processes, and facies assemblages. Journal of sedimentary research, 64.

BROWN, A. R., BROWN, A. R., BROWN, A. R. \& BROWN, A. R. 2004. Interpretation of three-dimensional seismic data, American Association of Petroleum Geologists Tulsa.

BROWN JR, L. \& FISHER, W. 1977. Seismic-Stratigraphic Interpretation of Depositional Systems: Examples from Brazilian Rift and Pull-Apart Basins: Section 2. Application of Seismic Reflection Configuration to Stratigraphic Interpretation.

BURGESS, P. M., WINEFIELD, P., MINZONI, M. \& ELDERS, C. 2013. Methods for identification of isolated carbonate buildups from seismic reflection data. AAPG bulletin, 97, 1071-1098.

CALVES, G., SCHWAB, A., HUUSE, M., VAN RENSBERgEN, P., CLIFT, P., TABREZ, A. \& INAM, A. 2010. Cenozoic mud volcano activity along the Indus Fan: offshore Pakistan. Basin Research, 22, 398413.

CARTWRIGHT, J., HADDOCK, R. \& PINHEIRO, L. 1993. The lateral extent of sequence boundaries. Geological Society, London, Special Publications, 71, 15-34.

CARTWRIGHT, J. A. \& JACKSON, M. P. A. 2008. Initiation of gravitational collapse of an evaporite basin margin: The Messinian saline giant, Levant Basin, eastern Mediterranean. Geological Society of America Bulletin, 120, 399-413.

DAVIES, R., BELL, B. R., CARTWRIGHT, J. A. \& SHOULDERS, S. 2002. Three-dimensional seismic imaging of Paleogene dike-fed submarine volcanoes from the northeast Atlantic margin. Geology, 30, 223-226. 
582

583

584

585

586

587

588

589

590

591

592

593

594

595

596

597

598

599

600

601

602

603

604

605

606

607

608

609

610

611

612

613

614

615

616

617

618

619

620
DAVIES, R. J., BRUMM, M., MANGA, M., RUBIANDINI, R., SWARBRICK, R. \& TINGAY, M. 2008. The East Java mud volcano (2006 to present): An earthquake or drilling trigger? Earth and Planetary Science Letters, 272, 627-638.

DAVIES, R. J. \& STEWART, S. A. 2005. Emplacement of giant mud volcanoes in the South Caspian Basin: 3D seismic reflection imaging of their root zones. Journal of the Geological Society, 162, 1-4.

DOLSON, J., BOUCHER, P., SIOK, J. \& HEPPARD, P. Key challenges to realizing full potential in an emerging giant gas province: Nile Delta/Mediterranean offshore, deep water, Egypt. Geological Society, London, Petroleum Geology Conference series, 2005. Geological Society of London, 607-624.

DUPRÉ, S., MASCLE, J., FOUCHER, J.-P., HARMEGNIES, F., WOODSIDE, J. \& PIERRE, C. 2014. Warm brine lakes in craters of active mud volcanoes, Menes caldera off NW Egypt: evidence for deeprooted thermogenic processes. Geo-Marine Letters, 34, 153-168.

DUPRÉ, S., WOODSIDE, J., KLAUCKE, I., MASCLE, J. \& FOUCHER, J.-P. 2010. Widespread active seepage activity on the Nile Deep Sea Fan (offshore Egypt) revealed by high-definition geophysical imagery. Marine Geology, 275, 1-19.

FAUGÈRES, J.-C., STOW, D. A., IMBERT, P. \& VIANA, A. 1999. Seismic features diagnostic of contourite drifts. Marine Geology, 162, 1-38.

GARCIA-CASTELLANOS, D., ESTRADA, F., JIMÉNEZ-MUNT, I., GORINI, C., FERNÁNDEZ, M., VERGÉS, J. \& DE VICENTE, R. 2009. Catastrophic flood of the Mediterranean after the Messinian salinity crisis. Nature, 462, 778-781.

GIRESSE, P., LONCKE, L., HUGUEN, C., MULLER, C. \& MASCLE, J. 2010. Nature and origin of sedimentary clasts associated with mud volcanoes in the Nile deep-sea fan. Relationships with fluid venting. Sedimentary Geology, 228, 229-245.

GRAUE, K. 2000. Mud volcanoes in deepwater Nigeria. Marine and Petroleum Geology, 17, 959-974.

HUGUEN, C., FOUCHER, J. P., MASCLE, J., ONDREAS, H., THOUEMENT, M., GONTHARET, S., STADNITSKAIA, A., PIERRE, C., BAYON, G. \& LONCKE, L. 2009. Menes caldera, a highly active site of brine seepage in the Eastern Mediterranean sea:" In situ" observations from the NAUTINIL expedition (2003). Marine Geology, 261, 138-152.

IADANZA, A., SAMPALMIERI, G., CIPOLLARI, P., MOLA, M. \& COSENTINO, D. 2013. The "Brecciated Limestones" of Maiella, Italy: rheological implications of hydrocarbon-charged fluid migration in the Messinian Mediterranean Basin. Palaeogeography, Palaeoclimatology, Palaeoecology, 390, 130-147.

KIRKHAM, C., CARTWRIGHT, J., HERMANRUD, C. \& JEBSEN, C. 2017a. The genesis of mud volcano conduits through thick evaporite sequences. Basin Research.

KIRKHAM, C., CARTWRIGHT, J., HERMANRUD, C. \& JEBSEN, C. 2017b. The spatial, temporal and volumetric analysis of a large mud volcano province within the Eastern Mediterranean. Marine and Petroleum Geology, 81, 1-16.

KOPF, A., KLAESCHEN, D. \& MASCLE, J. 2001. Extreme efficiency of mud volcanism in dewatering accretionary prisms. Earth and Planetary Science Letters, 189, 295-313.

LONCKE, L., MASCLE, J. \& PARTIES, F. S. 2004. Mud volcanoes, gas chimneys, pockmarks and mounds in the Nile deep-sea fan (Eastern Mediterranean): geophysical evidences. Marine and Petroleum Geology, 21, 669-689.

MACGREGOR, D. S. 2012. The development of the Nile drainage system: integration of onshore and offshore evidence. Petroleum Geoscience, 18, 417-431.

MAGEE, C., HUNT-STEWART, E. \& JACKSON, C. A.-L. 2013. Volcano growth mechanisms and the role of sub-volcanic intrusions: Insights from 2D seismic reflection data. Earth and Planetary Science Letters, 373, 41-53.

MASCLE, J., MARY, F., PRAEG, D., BROSOLO, L., CAMERA, L., CERAMICOLA, S. \& DUPRÉ, S. 2014. Distribution and geological control of mud volcanoes and other fluid/free gas seepage features in the Mediterranean Sea and nearby Gulf of Cadiz. Geo-Marine Letters, 34, 89-110.

MAZZINI, A. \& ETIOPE, G. 2017. Mud volcanism: An updated review. Earth-Science Reviews. 
635

636

637

638

639

640

641

642

643

644

645

646

647

648

649

650

651

652

653

654

655

656

657

658

659

660

661
MAZZINI, A., ETIOPE, G. \& SVENSEN, H. 2012. A new hydrothermal scenario for the 2006 Lusi eruption, Indonesia. Insights from gas geochemistry. Earth and Planetary Science Letters, 317, 305-318. MAZZINI, A., SVENSEN, H., AKHMANOV, G., ALOISI, G., PLANKE, S., MALTHE-SØRENSSEN, A. \& ISTADI, B. 2007. Triggering and dynamic evolution of the LUSI mud volcano, Indonesia. Earth and Planetary Science Letters, 261, 375-388.

MEIJER, P. T. \& KRIJGSMAN, W. 2005. A quantitative analysis of the desiccation and re-filling of the Mediterranean during the Messinian Salinity Crisis. Earth and Planetary Science Letters, 240, 510-520.

MEILIJSON, A., STEINBERG, J., HILGEN, F., BIALIK, O., ILNER, P., WALDMANN, N. \& MAKOVSKY, Y. Integrated stratigraphy and chronology of Messinian evaporites from the Levant basin in the deep eastern Mediterranean. EGU General Assembly Conference Abstracts, 2017. 5803.

MILKOV, A. V. 2000. Worldwide distribution of submarine mud volcanoes and associated gas hydrates. Marine Geology, 167, 29-42.

MITCHUM JR, R. M. 1985. Seismic stratigraphic expression of submarine fans: chapter 7.

OSBORNE, M. J. \& SWARBRICK, R. E. 1997. Mechanisms for generating overpressure in sedimentary basins; a reevaluation. AAPG Bulletin, 81, 1023-1041.

PIERRE, C., BAYON, G., BLANC-VALLERON, M.-M., MASCLE, J. \& DUPRÉ, S. 2014. Authigenic carbonates related to active seepage of methane-rich hot brines at the Cheops mud volcano, Menes caldera (Nile deep-sea fan, eastern Mediterranean Sea). Geo-Marine Letters, 34, 253-267.

PIERRE, C., ROUCHY, J.-M. \& BLANC-VALLERON, M.-M. 2002. Gas hydrate dissociation in the Lorca Basin (SE Spain) during the Mediterranean Messinian salinity crisis. Sedimentary Geology, 147, 247-252.

PRINZHOFER, A. \& DEVILLE, E. 2013. Origins of hydrocarbon gas seeping out from offshore mud volcanoes in the Nile delta. Tectonophysics, 591, 52-61.

ROUCHY, J. M. \& CARUSO, A. 2006. The Messinian salinity crisis in the Mediterranean basin: a reassessment of the data and an integrated scenario. Sedimentary Geology, 188, 35-67.

ROVERI, M., GENNARI, R., LUGLI, S., MANZI, V., MINELLI, N., REGHIZZI, M., RIVA, A., ROSSI, M. E. \& SCHREIBER, B. C. 2016. The Messinian salinity crisis: open problems and possible implications for Mediterranean petroleum systems. Petroleum Geoscience, petgeo2015-089.

RUDOLPH, M., SHIRZAEI, M., MANGA, M. \& FUKUSHIMA, Y. 2013. Evolution and future of the Lusi mud eruption inferred from ground deformation. Geophysical Research Letters, 40, 1089-1092.

RUDOLPH, M. L., KARLSTROM, L. \& MANGA, M. 2011. A prediction of the longevity of the Lusi mud eruption, Indonesia. Earth and Planetary Science Letters, 308, 124-130.

STEWART, S. A. \& DAVIES, R. J. 2006. Structure and emplacement of mud volcano systems in the South Caspian Basin. AAPG bulletin, 90, 771-786.

VAHRENKAMP, V. C., DAVID, F., DUIJNDAM, P., NEWALL, M. \& CREVELLO, P. 2004. Growth architecture, faulting, and karstification of a middle Miocene carbonate platform, Luconia Province, offshore Sarawak, Malaysia.

ZHAO, F., WU, S., SUN, Q., HUUSE, M., LI, W. \& WANG, Z. 2014. Submarine volcanic mounds in the Pearl River Mouth Basin, northern South China Sea. Marine Geology, 355, 162-172. 


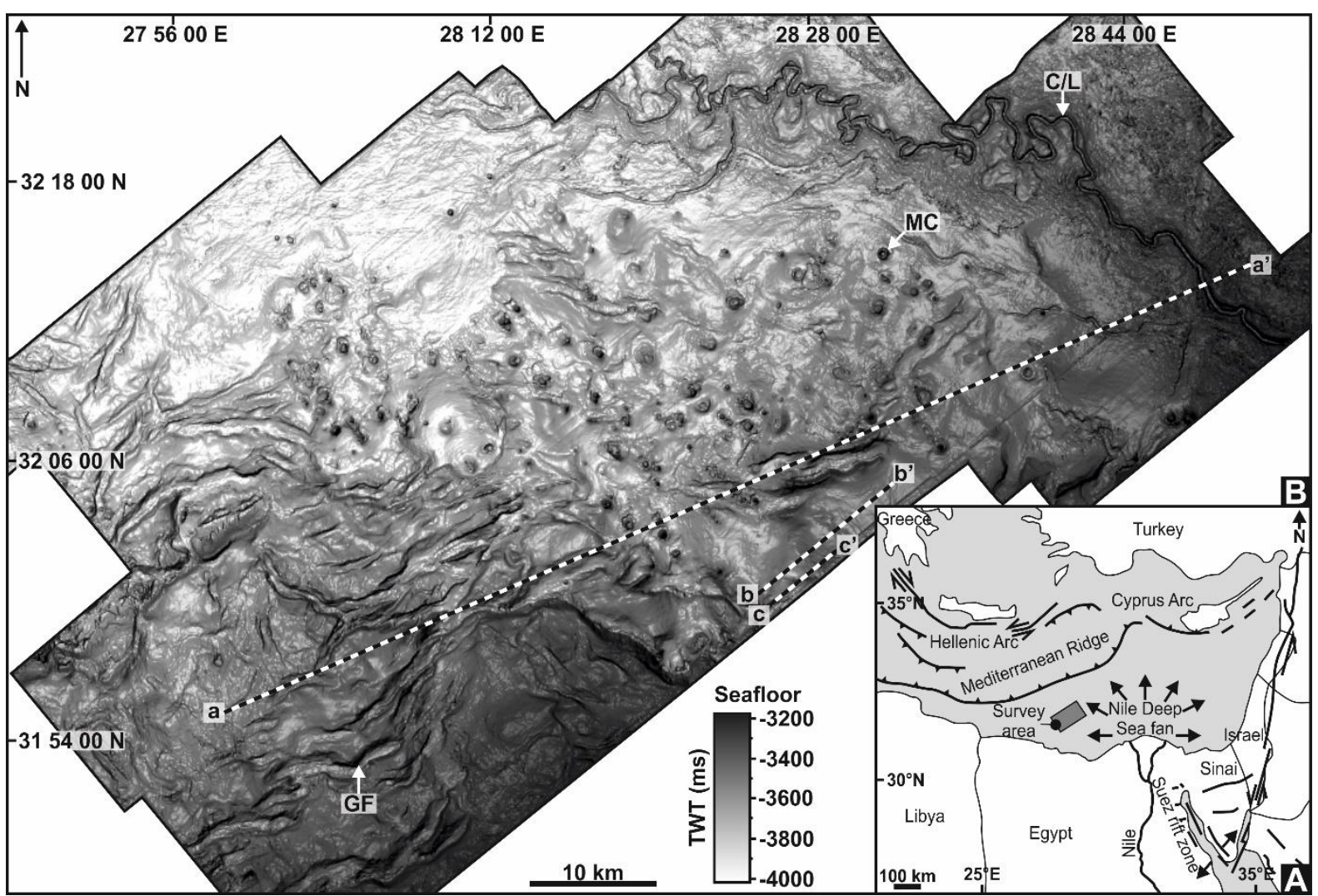

Figure 1. (A) Map of the Eastern Mediterranean showing the location of the study region within the western Nile Cone. The location of the 3D seismic survey is highlighted, offshore Egypt. (B) Seafloor map within this seismic study area. Prominent geomorphological features include a large number of circular mud cones (MC) primarily distributed within the central region of the study area, numerous growth faults (GF) to the southwest and a channel/levee system $(C / L)$ to the northeast. The lines of seismic section in Figure $2\left(a-a^{\prime}\right)$ and Figure $4\left(b^{\prime}-b^{\prime}\right.$ and $\left.c-c^{\prime}\right)$ are displayed.

673

674

675 




Figure 2. (A) An un-interpreted pre-stack depth migrated seismic cross-section through the study area (see 678 line a-a' in Figure 1B for location). (B) The same seismic cross-section as in Figure 2A, but with interpretation of the stratigraphy. The seismic cross section displays the main stratigraphic units and the presence of the locally developed 'soft' reflection of Horizon L (L) above the top of the Messinian Evaporites (ME). The PostEvaporitic Unit (POE) is also host to a large number of mud volcanoes (MV) and contains numerous normal 682 faults that detach within the Messinian Evaporites. Sf - Seafloor; M - Horizon M (top-evaporites); N - Horizon 683 N (base-evaporites); PE - Pre-Evaporitic Unit. 

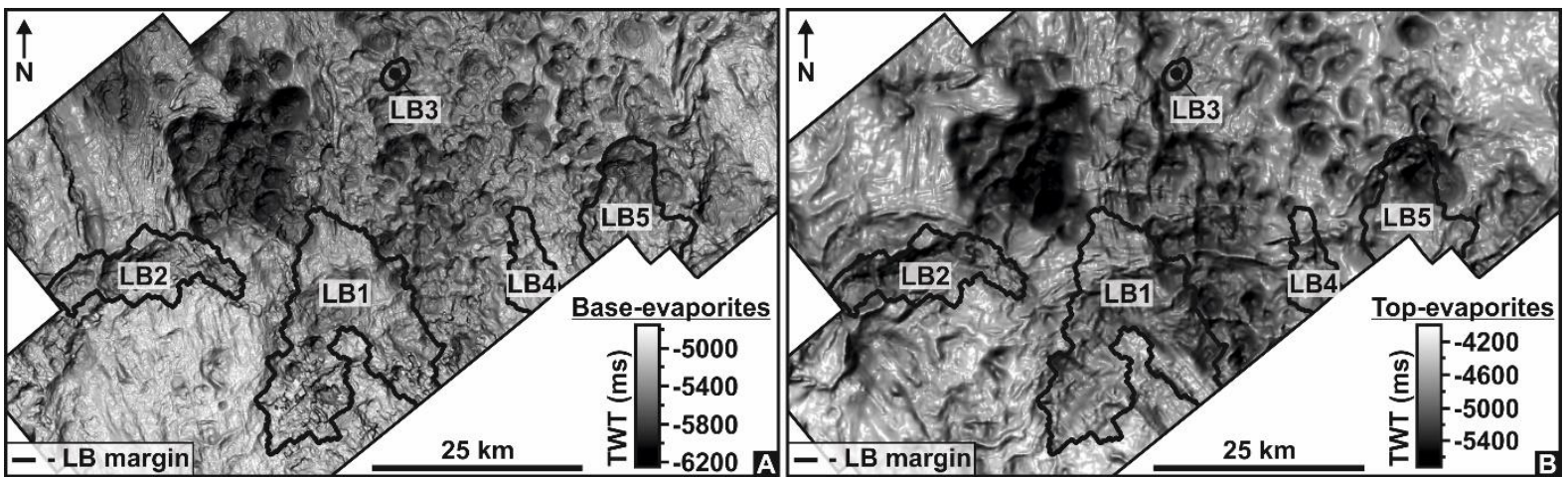

Figure 3. (A) A base-evaporites map that exhibits numerous prominent depressions and ridges of relief, some of which are located beneath lensoid bodies. (B) A top-evaporites map that exhibits numerous prominent depressions, some of which spatially underly lensoid bodies (LB). Outlines of the margins of all five identified lensoid bodies (LB1, LB2, LB3, LB4 and LB5) are displayed in both A and B. 


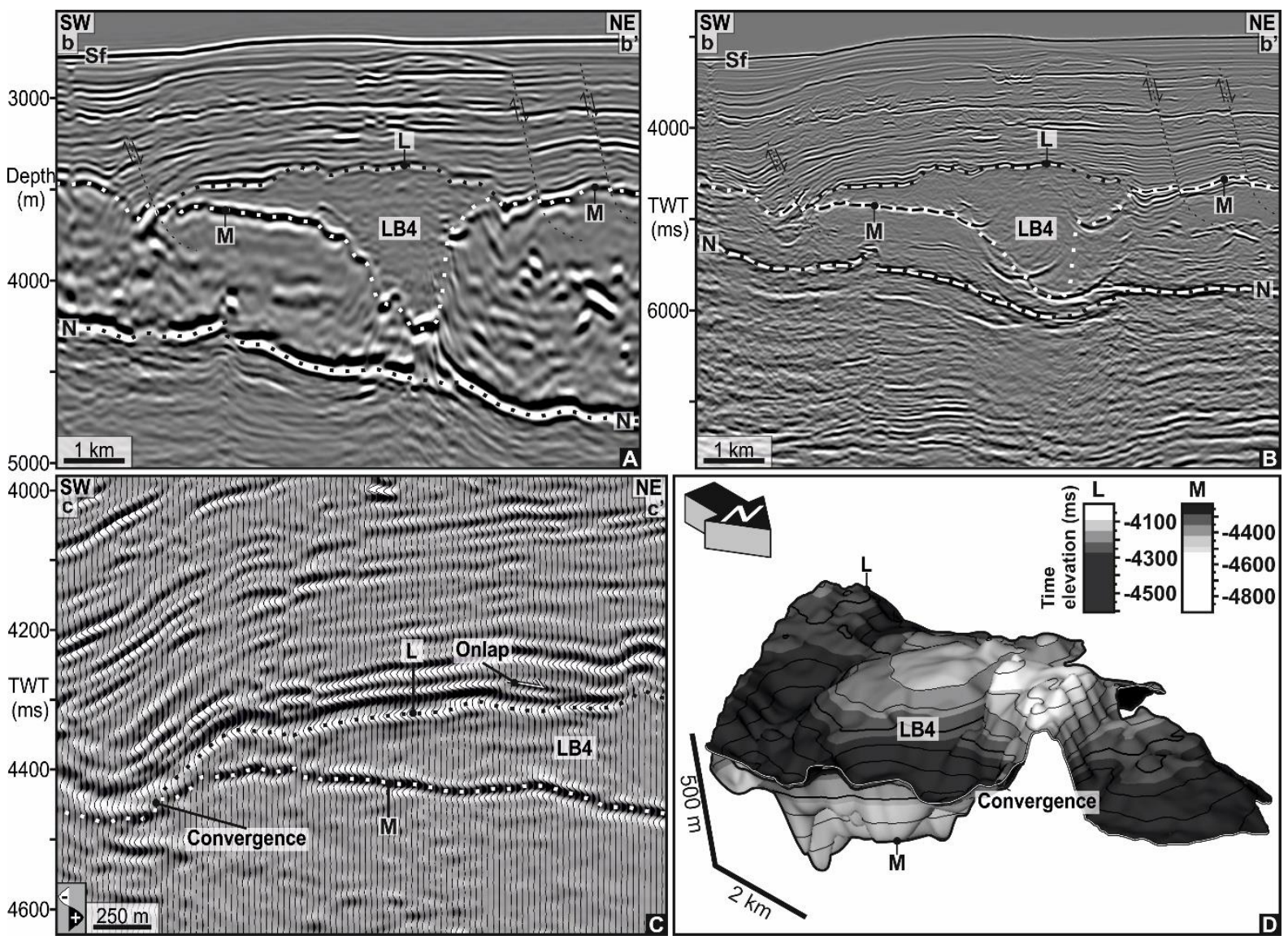

Figure 4. (A) Pre-stack depth migrated seismic cross-section through Lensoid Body 4 (LB4) (see Figure 1B for line of section). B: Pre-stack time migrated seismic cross-section through LB4 (Same line of section as in Figure 4A). C: Zoomed seismic cross-section with the wiggle trace displayed through the lateral margin of LB4, displaying the 'soft' reflection of Horizon L (L) converging with the 'hard' reflection of Horizon $M(M)$ and onlapping of hemipelagites onto Horizon L (see Figure 1B for line of section). D: 3D model of LB4 comprising the Horizon $L$ and Horizon M. Horizon L and Horizon $M$ converge at the lateral margins of the lensoid body. SF - Seafloor; $\mathbf{N}$ - Horizon $\mathbf{N}$. 
Table 1.

753 Lensoid body dimensions recorded from 3D seismic data.

\begin{tabular}{|l|c|c|c|c|c|c|}
\hline & Longitude & Latitude & $\begin{array}{c}\text { Max vertical } \\
\text { thickness } \\
(\mathbf{m})\end{array}$ & Area $\mathbf{( k m}^{\mathbf{2}} \mathbf{)}$ & $\begin{array}{c}\text { Volume } \\
\left(\mathbf{k m}^{\mathbf{3}} \mathbf{)}\right.\end{array}$ & $\begin{array}{c}\text { Upper } \\
\text { surface } \\
\text { relief }(\mathbf{m})\end{array}$ \\
\hline LB1 & $28.24401 \mathrm{E}$ & $32.01514 \mathrm{~N}$ & 900 & 315 & 116 & 300 \\
\hline LB2 & $28.00300 \mathrm{E}$ & $32.08393 \mathrm{~N}$ & 1170 & 122 & 52 & 450 \\
\hline LB3 & $28.30696 \mathrm{E}$ & $32.28446 \mathrm{~N}$ & 640 & 8 & 1.25 & 250 \\
\hline LB4 & $28.47415 \mathrm{E}$ & $32.06930 \mathrm{~N}$ & 730 & 46 & 11 & 350 \\
\hline LB5 & $28.60079 \mathrm{E}$ & $32.14085 \mathrm{~N}$ & 1010 & 105 & 36 & 280 \\
\hline
\end{tabular}




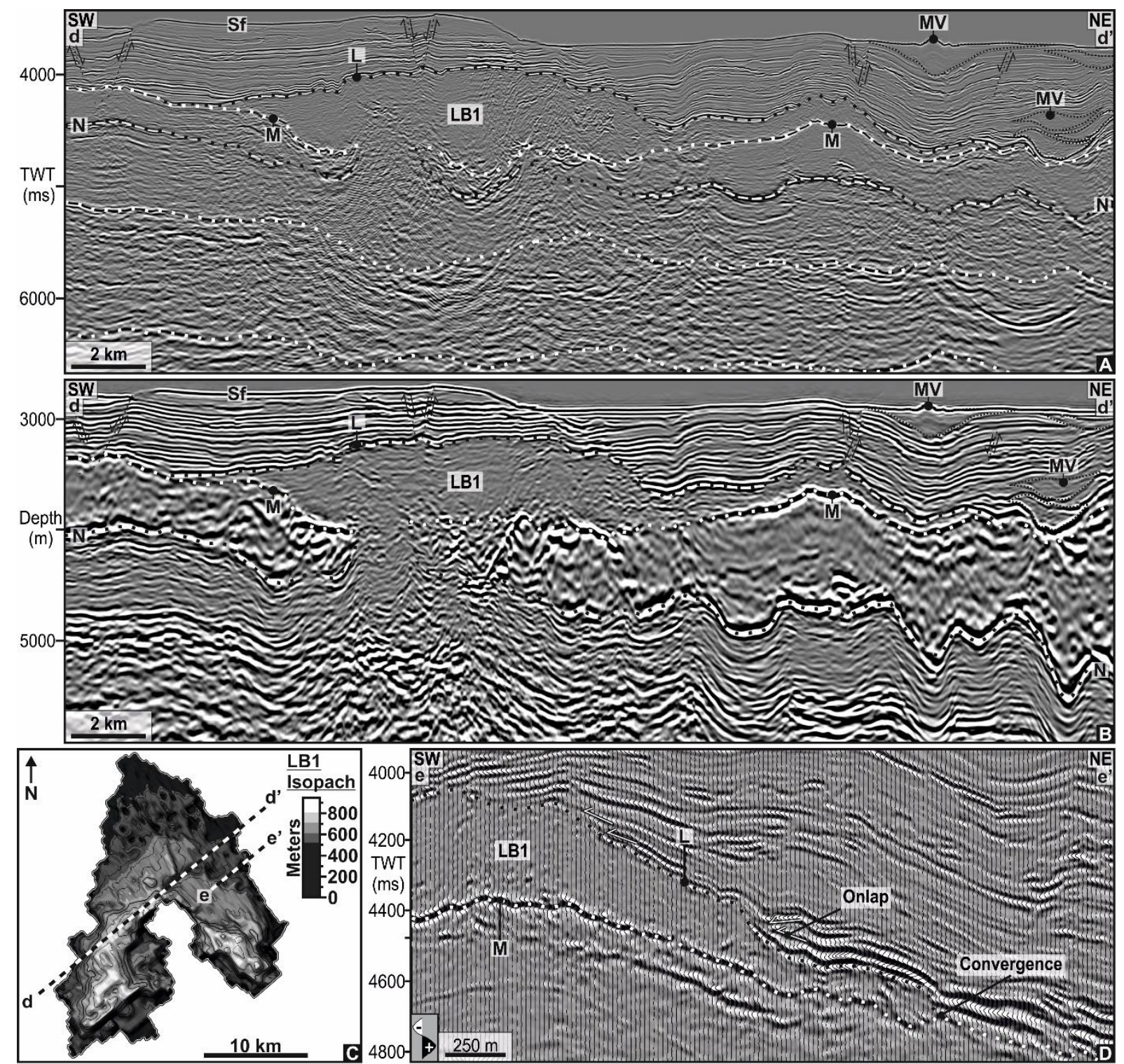

Figure 5. (A) Pre-stack time migrated seismic cross-section showing lensoid body 1 (LB1) directly on top of Horizon $\mathrm{M}(\mathrm{M})$ and several mud volcanoes (MV) and normal faults within the Post-Evaporitic Unit (see Figure 5C for line of section). (B) Pre-stack depth migrated seismic cross-section through LB1. A connection between the Pre-Evaporitic Unit and LB1 is visible (Same line of section as in Figure 5A). (C) Isopach map of LB1, displaying the irregular planform geometry and thickness variation (see Figure 3 for location of LB1). (D) Zoomed seismic cross-section of the flanks of LB1 with the wiggle trace displayed, showing the thinning of the

773 lensoid body towards its lateral margins, the polarity and convergence of Horizon $L(L)$ and Horizon $M$ and onlap onto Horizon L (see Figure $5 \mathrm{C}$ for line of section). Sf - Seafloor; $\mathbf{N}-$ Horizon $\mathbf{N}$. 

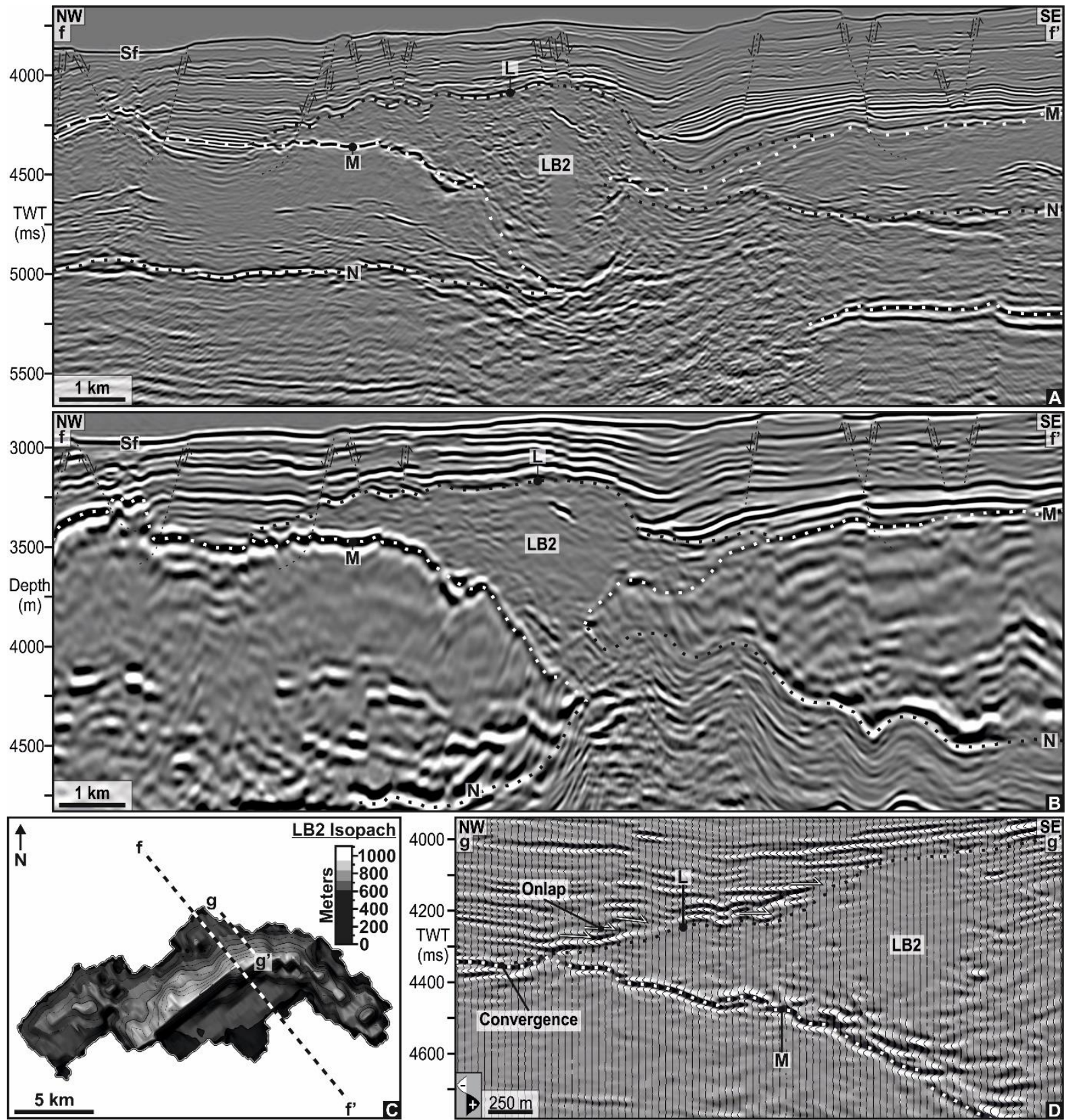

Figure 6. (A) Pre-stack time migrated seismic cross-section showing lensoid body 2 (LB2) directly on top of Horizon $M(M)$ and faulting of the Post-Evaporitic Unit (see Figure $6 C$ for line of section). (B) Pre-stack depth migrated seismic cross-section through LB2. A connection between the Pre-Evaporitic Unit and LB2 is clearly displayed (Same line of section as in Figure 6A). (C) Isopach map of LB2, displaying the irregular and elongated planform geometry and thickness variation. The lensoid body is thickest at a central ridge (see Figure $\mathbf{3}$ for location of LB2). (D) Zoomed seismic cross-section of the lateral margin of LB2 with the wiggle trace displayed, showing convergence of Horizon $L(L)$ and Horizon $M$ and onlap onto Horizon $L$ (see Figure $6 C$ for line of section). Sf - Seafloor; $\mathrm{N}$ - Horizon $\mathbf{N}$. 


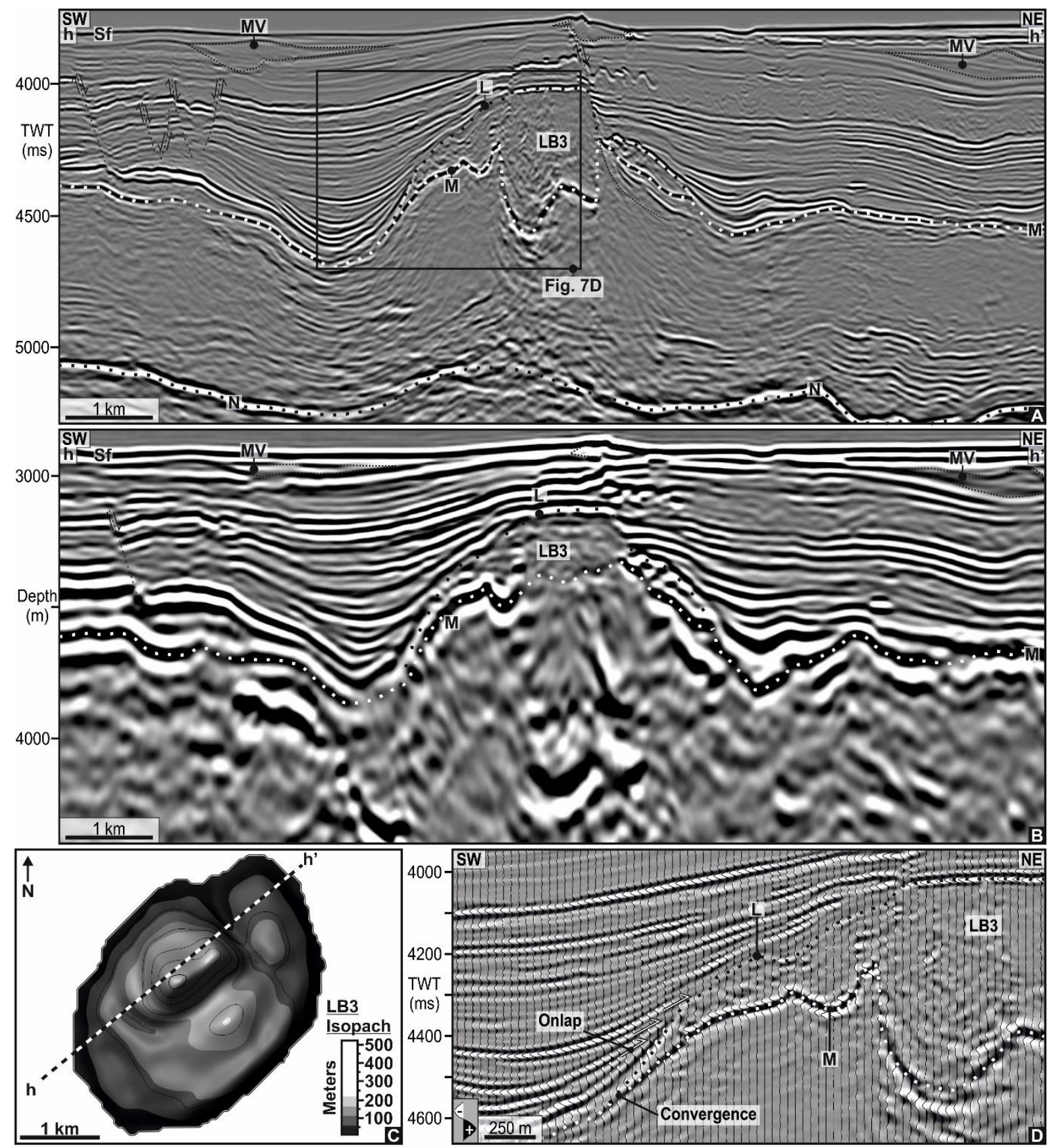

Figure 7. (A) Pre-stack time migrated seismic cross-section showing lensoid body 3 (LB3) directly on top of Horizon $M(M)$. The lensoid body is deformed by faulting in the Post-Evaporitic Unit (see Figure $7 \mathrm{C}$ for line of section). (B) Pre-stack depth migrated seismic cross-section through LB3 (Same line of section as in Figure 7A). (C) Isopach map of LB3, displaying the elliptical planform geometry and maximum thickness centrally and thinning toward the lateral margins (see Figure 3 for location of LB3). (D) Zoomed seismic cross-section of the lateral margin of LB3 with the wiggle trace displayed, showing convergence of Horizon $L(L)$ and Horizon $M$ (M) and onlap onto Horizon L (see Figure 7A for line of section). Sf - Seafloor; $\mathrm{N}$ - Horizon N. 


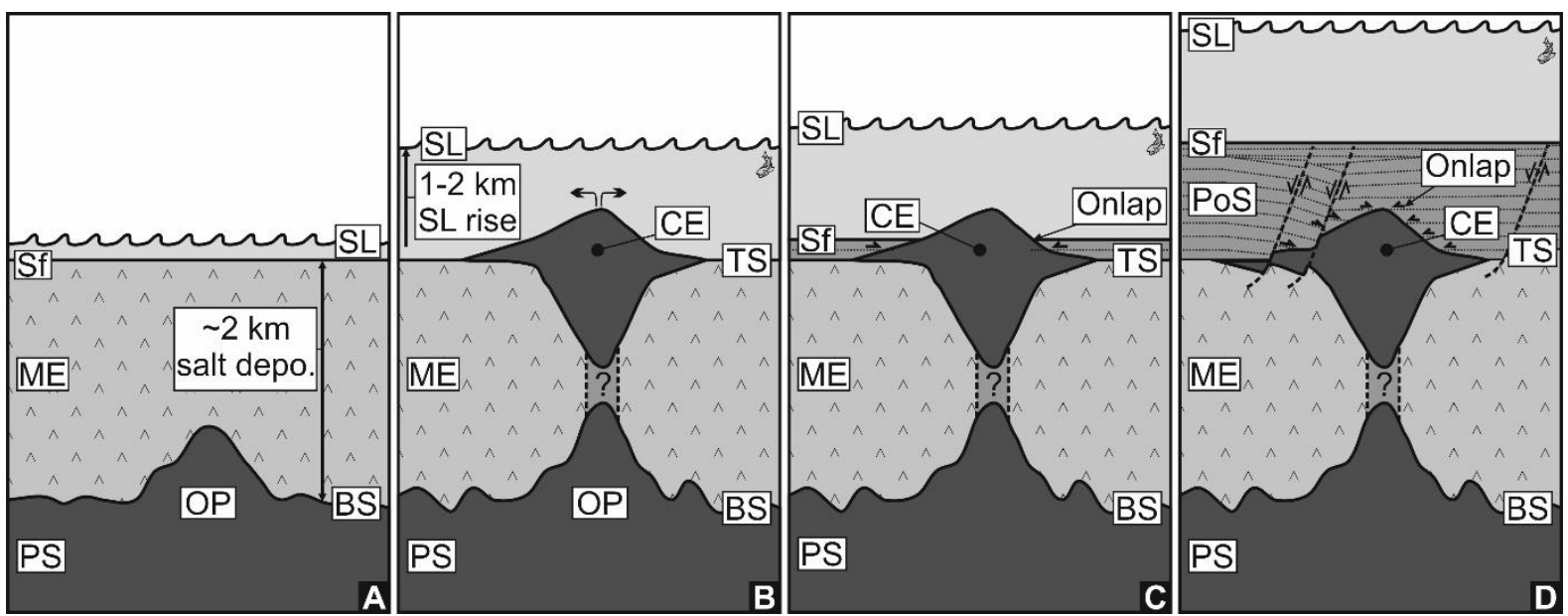

Figure 8. A schematic model for the genesis of giant clastic extrusions within the western Nile Cone. Their formation has been divided into 4 stages (A-D). The description of these stages can be found in the 'Overpressure and remobilisation mechanisms' section of the discussion. SL - Sea level; Sf - Seafloor; OP Overpressure; CE - Clastic extrusion; TE - Top-evaporites; BE - Base-evaporites; PoE - Post-Evaporitic Unit; ME - Messinian Evaporites; PE - Pre-Evaporitic Unit. 


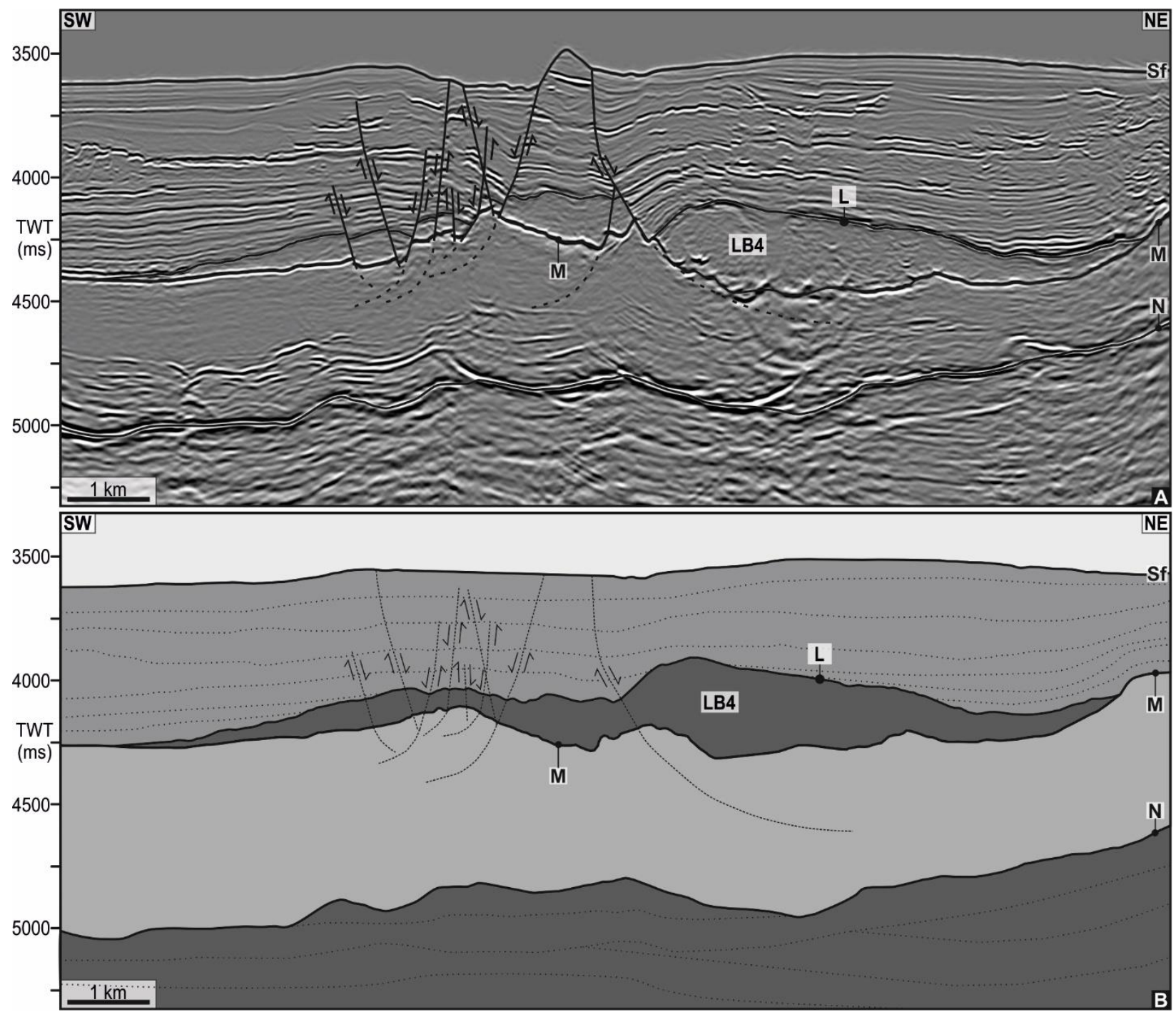

820 migrated seismic cross-section through lensoid body 4 (LB4). Faults that transect through the

821 Pliocene-Recent succession and detach within the underlying Messinian Evaporites have also

822 propagated through the lensoid body. This has led numerous instances where the top and

823 base of the lensoid body (Horizon L (L) and Horizon M (M)) are displaced, contributing

824 significantly its irregular present day geometry. (B) A reconstruction of LB4 that accounts for

825 the displacement of the lensoid body by numerous faults, in order to produce a cross-section 
826 which demonstrates the less irregular geometry of LB4 when not faulted. Sf - Seafloor; N -

827 Horizon N.

828
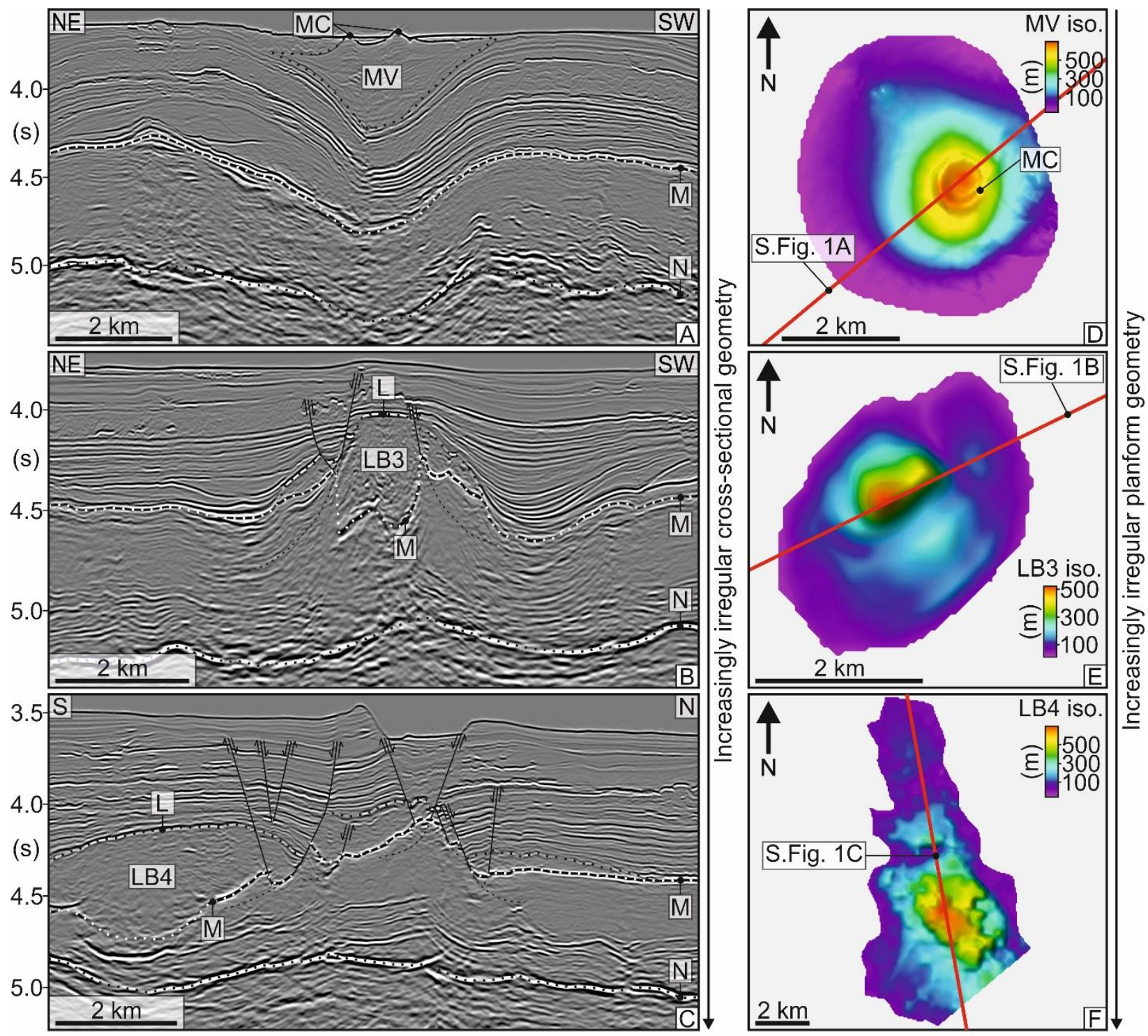

Increasingly irregular 3D geometry

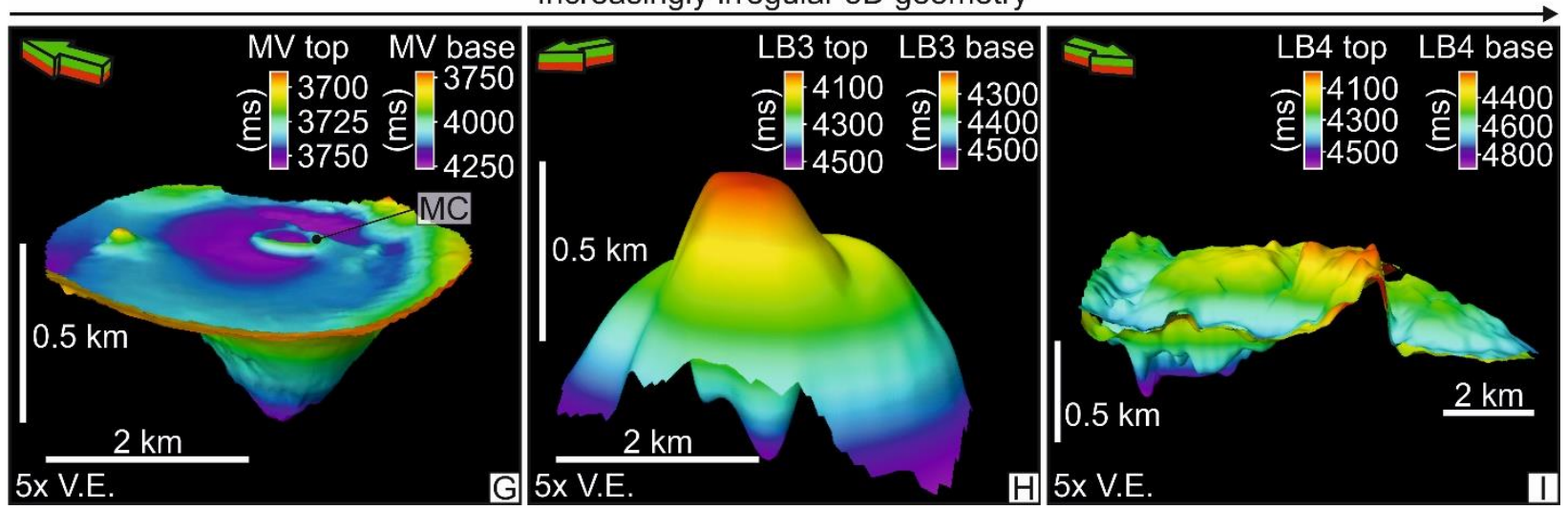


831 to lensoid bodies (giant clastic extrusions) of increasing size. (A) Pre-stack time migrated

832 seismic cross-section through one of almost 400 small and conical mud volcanoes within the

833 3D seismic survey. The base of the mud volcano (MV) and underlying Pliocene-Recent

834 succession exhibit a concave upward geometry due to subsidence. The MV is thickest

835 centrally and thins towards its margins where its upper and lower surfaces converge. (B) Pre-

836 stack time migrated seismic cross-section through lensoid body 3 (LB3). Similar to the MV in

837 Sup. Fig. 2A the lensoid body is thickest centrally and thins towards the convergence of its top

838 and base (Horizon L (L) and the top of the evaporites (M)). The cross-sectional geometry of

839 LB3 is slightly more irregular than the small conical MV in Sup. Fig. 2A due to faulting and

840 subsidence towards the flanks of the body. (C) Pre-stack time migrated seismic cross section

841 through lensoid body 4 (LB4). Several faults propagate through the Pliocene-Recent

842 succession and lensoid body. The throw along these faults compartmentalizes the lensoid

843 body and detach within the underlying evaporites. This results in a very irregular geometry to

844 the lensoid body, even more so than LB3 in Sup. Fig. 2B. (D) A planform isopach map of the

845 small conical MV in Sup. Fig. 2A, exhibiting a circular-elliptical planform and isopach

846 distribution that is greatest at its centre and decreases toward the MVs margins. (E) A

847 planform isopach map of LB3 that exhibits an elliptical planform and an isopach distribution

848 that is greatest at its centre and decreases toward the lensoid bodies margins, similar to the

849 MV in Sup. Fig. 2D. (F) A planform isopach map of LB4 that exhibits an irregular planform that

850 contrasts with the planform of the small conical MV and LB3. Its thickness is greatest centrally

851 and thins towards the margins, similar to the conical MV and LB3, however, LB4 thins more

852 gradually northwards. (G) A 3D model of the small and conical MV in Sup. Fig. 2A that exhibits

853 the classical geometry of a mud volcano visible at the present day seafloor within this region 
854 of the Eastern Mediterranean. (H) A 3D model of LB3 that exhibits a conical shape but a 855 slightly more irregular 3D geometry than the small conical MV in Sup. Fig. 2G. (I) A 3D model 856 of LB4, the size of which is larger than LB3 and the small conical MV, and exhibits an even

857 more irregular 3D geometry than LB3. MC - Mud cone; $\mathrm{N}-$ Horizon N

858

859 